\title{
A Paradigmatic Study to Legally Assess the Authority and Right of Jurisdiction of Public Sector Governance: Examining Discretion in Government Administrative Law
}

\author{
Tasman Gultom, Erlyn Indarti and Nabitatus Sa'adah
}

\author{
Diponegoro University, Semarang, Indonesia
}

\begin{abstract}
This study aims to explore how government administration has so far been carried out within the authority framework of discretion owned by government agencies. This study uses a qualitative method with a descriptive normative analysis approach to obtain a paradigmatic study as a legal assessment to investigate the authority and right of jurisdiction of public sector governance. The focal point was to examine discretion in government administrative law as contained in Law No. 30 of 2014 about Government Administration. The results showed that as a freedom of thought and action in legalization, discretionary authority lies in the authority to carry out positions held by government administrative officials. The results also highlight that discretion is still rigid in its application in Indonesia because the procedure to perform this discretion is tiered. The theoretical implication revealed that the difference has led to controversy between scientific discretion and the discretion contained in the Law on Government Administration, decreasing public official's willingness to do something for the benefit and welfare of society and seekers of justice.
\end{abstract}

Keywords: Legal assessment, authority, public sector, governance, discretion, government administration.

\section{INTRODUCTION}

Indonesia, a state based on justice and integrity, declared that Indonesia is a state based on the law (rechtstaat) and not based on power (machtstaat). The statement mentioned is regulated in the 1945 Constitution, Article 1(3) determined that Indonesia is a state based on the rule of law (Entah, 2016). In order to organize government administration, the government owns various authorities. Authority has an important position in Constitutional Law and State Administrative Law studies. Stroink \& Steenbeek (1989) stated authority is the core of Constitutional Law and State Administrative Law (Minarno, 2007). Authority must be based on the terms of the constitution so that the authority is valid. The government's institution authority is an authority that strengthens by positive law in order to regulate and maintain it. Without the authority, the right verdict of jurisdiction cannot be issued (Rasyid, 2004). As the main organizer of public service management authority both in central and local government, government officials have wide authority in running for government. This wide authority was obtained from the written law of legislation. In the state administrative law concept, actions outside the written law can be justified so the principle of legality in the operational step can be done dynamically, effectively, and efficiently. This concept is known as "discretion" (Elliott et al., 2011). The use of discretionary authority must be based on limited goals, as regulated in Article

*Address correspondence to this author at the Diponegoro University, Semarang, Indonesia; E-mail: tgultom.undip@gmail.com
22(2) of Government Administration Law which is, smoothen the governance's coordination, filling a legal vacuum, and resolving government stagnation (Saraswati et al., 2020). In conducting state administration duties, the government issued many policies which manifested in various forms such as policies, wisdom, regulations, guidelines, circular letter, resolutions, instructions, policy notes, ministerial regulation, and verdicts (Yuhdi, 2013).

Discretion is defined as one of the mediums that give latitude for officials or state administrative agencies to act without fully attached to the regulations, or an action taken by prioritizing goal achievements (doelmatigheid) over the applicable law (rechmatigheid) (Ridwan, 2009; Ansori, 2017). Discretionary authority lies in the authority to carry out positions held by government administrative officials. Discretionary authority is a type of authority to use power based on the initiative of government administration officials. This authority is given by the regulation so that the officials can complete their duties properly. This kind of conditions are prone to be manipulated by the officials because it coincides with implementing public policies; there is an intention to gain personal or group advantages. Discretionary usage has a specific requirement in order to prevent the officials to act arbitrarily in using the authority (Sihotang et al., 2017).

Basically, discretion is something that cannot be avoided for both law enforcement and their acts in fulfilling their duties, even though it seems to contradict with rule of law on the surface. The nature of regulations which open logically, made discretion's 
elements, at least the implicit one cannot be rejected. Naturally, discretion attaches and merges with the individual and law enforcement institution. For the consequence, discretion also attaches naturally in duties implementations (Indarti, 2010). As part of governmental duties implementations and social services, policymaking authority is attached to a government position (inherent aan het bestuur) which run by the government officials, apparently, it made many of officials become a suspect or even a convict. This caused by a policy, in general, that does not run cooperatively or it is not arranged yet in legislation. It is said that government policy cannot be questioned legally, in fact, in every practice held before, the policymaker had processed legally and pointed as a suspect or even a convict. Questions raise upon this problem; in what way occupational responsibilities and personal responsibilities applied in terms of government policy? Is there any legal norms limitation that can be applied towards the government policy?

\section{LITERATURE REVIEW}

Discretion has an important role in every aspect of the life of people and of the nation (Elliott et al., 2011). Foremost, in filling the written provisions emptiness along with flexing rigid and out of date provisions. Moreover, it adjusts with up-to-date and advantageous context for the public (Susilo, 2015). Discretion means the freedom in taking own decision in a particular situation. In discretion definition regulation based on Article 1(9) of Government Administration Law discretion is the decision and/or actions that have been settled and/or has been done by government officials to resolve the concrete problem faced in governance in terms of legislation which give choices, not regulate, not complete or not clear, and/or the existence of government stagnation. In its implementation, discretion is one of state administrative officials' right to complete their duties but it has to be the one who has the authority. Officials' decision or action's meaning is different based on terminology but basically, it has the same goal. Decisions are related to the action that had been done through a provision in form of determination meanwhile action can be defined as direct treatment by officials without determination.

Officials' decisions or actions in the form of discretion cannot be implemented immediately because discretion execution must meet specific requirements correspond with Article 22 Law No. 30 of 2014, which smoothens the governance's coordination, filling a legal vacuum, giving legal certainty and resolving government stagnation in certain situation for expediency and public interest. This article reflects the importance of discretion usage because in its application, not all regulation can reach official's duties, authorities and responsibilities comprehensively especially the technical implementation so that it needs the official's subjective action in completing their duties. It is clearly stated in Article 23 the reason why discretion is given, including the legislative requirements which giving decision and/or action choice, not regulated legislation, not complete or not clear legislation, and the emerge of government stagnation for wider interest.

This discretion usage parameter is much more concrete explained as following. The first is related to choices given by the legislation, in this term, an official is faced with two action choices, from that two alternative choices, the official is given the freedom to choose one of the choices so the chosen choice is called discretion. The second is related that it is not regulated legislation, not complete or not clear in terms of there is still no regulation yet related to the technical implementation of the duty, not completed or it has multiple meaning so an official must issue the discretion in order to avoid stagnation in completing the duty. Third, government stagnation emergence, this means as an emergency, urgent, and/or disaster situation. When there is an urgent situation then the officials are given freedom legally to take decisions or actions with the purpose to respond to the situation for the sake of public interest. It explained many times in legislation, moreover, a president can issue a presidential decree to substitute the legislation as the response in facing the urgent situation.

In Indonesian positive law discretionary authority has been regulated in several written legal norms. For instance, discretionary authority for law enforcement officer such as judge, prosecutor and police (Indarti, 2020; Mukhlis et al., 2020; Gulo et al., 2020; Bolifaar et al., 2019) related to this matter can be seen clearly in Article 31 (1) amended by Article 21(1) and (4) Penal Code of Indonesia amended by article 35 and $36 \mathrm{Gov}$. Reg. No. 27 of 1983 about the execution of Penal Code of Indonesia. The presence of subjective reasons is indeed giving discretion or freedom for investigating officers, public prosecutors, or judges to grant or not the objection plea claims over the arresting towards a suspect/ defendant. Article 31(1) Penal Code of Indonesia stated that at the request of a suspect or defendant, an investigator or public prosecutor or judge, in accordance with their respective authority, 
can hold a suspension of detention with or without money guarantee or personal guarantee based on specified conditions. It means the person sentenced to a fine may immediately serve the substitutive light imprisonment without awaiting the term of payment.

Because the use of imprisonment has been regulated in article 20(1), (2), and (3) Penal Code of Indonesia and with paying attention to article 31 (1) the official involved can conduct light imprisonment with or without bail or person with a certain condition. However, in practice, even though it has fulfilled the conditions legally, the request from the suspect's family or advocate about light imprisonment or suspect/ defendant's detention type alteration along with the bail is not certainly can be grant by law enforcement officer related. The reason is that the law enforcement officer related has discretionary authority to interpret the situation by themselves in order to either reject or grant the request.

Next, discretion arrangement in the police force can be seen in Article 18 (1) Law No. 2 of 2002 about Indonesian Police Force that mentions for the public interest they act according to their own assessment, which taken in a situation that needs to pay attention to legislation and also the ethical code of Indonesian National Police (Indarti, 2020). Discretion by state administrative officials, generally, actualized in the form of policy regulations. Laica Marzuki stated that the elements of policy regulations are issued by institution or official as a manifestation of free judgment (freies ermessen) in written form, which already formed written, then it is declared and enforced to the citizen (Widijowati, 2016). The content of policy regulations, in fact, is already a separate general rule, so it is no longer an operational implementation instruction, as it is the original intention of policy regulation itself. Institutions or officials which issued the policy regulation do not have the authority to make general regulation completely so far, but it is seen legitimated considering policy regulation related, no other than the manifestation of freies ermessen which formed written. Policy regulation's products are inseparable from freies ermessen where state administrative officials formulating their policy in a form of legal rules, which not along with regulation making authority from the officials which issued policy regulation and has been part of government activity. Policy regulation is not legislation, it is called pseudolaw or shadow law. Therefore, policy regulation is not tied legally but it has legal relevance.
Policy regulation characteristics applied by J.H Van Vreveld (1983) are stated that the regulations are direct or indirect, not based on formal law which gives regulate authority in another way, the basis of those regulations cannot be found in the Law. Moreover, the regulations are not written and appeared through series of decisions. Government instance's decision in completing free governmental authority towards a citizen, or determined in written form by the government instance-related. Lastly, the regulations give instruction generally, in other words, government instance carries out their free governmental authority towards each individual citizen who is in the defined situation (Patiro, 2012).

In the development, it is consciously that discretionary power in written form and published are given the predicate of regulation, because policy rule tied as a legal norm, the scope of policy regulations is only on the administrative field. Therefore, freies ermessen is included in policy regulations so that it is being in the administrative policy field. Thus, even though policy regulation is given "regulation" predicate, it is not included in the legislation, and not a part of the legislation. The difference between legislation and policy regulation is toward policy regulation, the trial cannot be done the same as legislation trial because the trial held indirectly based on the trust principle (vertrouwensbeginsel). Moreover, policy regulation contains a knowledge necessity in certain urgent circumstances, state administrative officials can divert from the regulation concerning the situation for public interest purposes and legislation is included fields of law and because it could be tested through court meanwhile policy regulation is included in fact world and that is why it does not play a role in the court (Hadjon, 2005).

\section{METHOD}

The method used in this research is the qualitative method with a descriptive normative analysis approach to obtain a clear and accurate depiction. The researchers attempt as much as possible to provide complete data on the research object. The researchers are examining using a library database which consists of books, journals, reports, Legislations, and digital sources from the internet and interviews.

The regulations used in this study include Law No. 30 of 2014 ruled about Government Administration. Moreover, in Indonesian positive law discretionary authority has been regulated in several written legal 
norms. For instance, discretionary authority for law enforcement officer (judge, prosecutor and police) related to this matter we can see it clearly in Article 31 (1) amended by Article 21 (1) and (4) Penal Code of Indonesia amended by article 35 and 36 Gov. Reg. No. 27 of 1983 about the execution of Penal Code of Indonesia. More specifically, the regulation used as a basis of analysis was discretion arrangement in the police force in Article 18 (1) Law No. 2 of 2002 about Indonesian Police Force.

\section{RESULT AND DISCUSSION}

Discretion as government authority is not only a free authority owned by government officials but also the opposite of bound authority. The characteristics of the government's act of law require the government is not just only conducting Law, but also must put forward goals establishment (doelstelling) and policies (beleid). This kind of government action is a form of active power. Discretion should not be misunderstood by government officials as a freely issued decision and/or action by their own will without obeying the fundamental, specifically for a public interest, in each jurisdictional boundary, and not violating good governance. Each authority in a state based on the rule of law does not recognize any authority which is as free as possible. Authority (including bound authority) always has a boundary ordered by legislation that can be tested through court and the policymaker will be burdened with responsibilities. There are two responsibilities, occupational responsibilities and personal responsibilities. Occupational responsibilities happen when the policymakers used discretion for and on behalf of their position, meanwhile personal responsibilities applied in a condition of when the policymakers did maladministration. In order to make government officials' decision and/or action discretion create a good administration system runs effectively, it must be done for the sake of public interest, conducted transparently, and attempted to include wider public participation.

Regarding discretion in government administration, the wider the participation of government in every aspect of social life, the wider the field of state administration that being carried out. State administration duties are also increasing because they must fulfill societal needs which getting more complex. In the welfare state concept, state administration duty is conducting public welfare (Muslimin, 1985). Even though government officials need to work quickly and efficiently, they also need to put forward transparency and accountability principle in carrying out their duty as government apparatus. Government officials are required to always do their actions and decisions based on the legality principle which has been a guide in carrying out their government duties (Mustafa, 1990). Law No. 30 of 2014 ruled about Government Administration has to follow discretion meaning expansion. Rule of discretion regulated in mentioned law starts from Article 25 until Article 32. The provision in those articles at least giving a clear legal certainty about discretion usage procedure. Besides, it also regulates discretion usage limitation by government institution/officials (Fathuddin, 2015).

The focus of theoretical and conceptual issues in analyzing discretion concept is the occurrence of tension between the act of carrying out the law (or wider legislation) legalistically versus deviating action from the law (or wider legislation). Logically, the last action mentioned is controversial without proper justification. For instance, the action can be qualified shortly as law violating; power misuses because yang the one who did it was government institutions/officials. It goes together with the negative evaluation of the discretion concept told by Herbert Packer (1966) that the basic trouble with discretion is simply that it is lawless, in the literal sense of that term (Post, 1984; Darumurti, 2014).

Law No. 30 of 2014 about Government Administration is one of the basic law for Institution and/or government official, public society, and other party related to government administration in an attempt to increase governance management quality. Government administration regulation in this Law guarantee the decision and/or action of the institution and/or government officials toward public society cannot be done arbitrarily. With this law, public society will not become a states power object easily. Furthermore, this Law is the transformation of good governance which has been practised for decades in managing governance and concretized into legal norms. In its implementation, discretion is one of state administrative officials' right to complete their duties but it has to be the one who has the authority. Officials' decision or action's meaning is different based on terminology but basically, it has the same goal. Decisions are related to the action that had been done through a provision in form of determination meanwhile action can be defined as direct treatment by officials without determination.

Officials' decisions or actions in the form of discretion cannot be implemented immediately 
because discretion execution must meet specific requirements correspond with Article 22 of Law No. 30 of 2014, which smoothens the governance's coordination, filling a legal vacuum, giving legal certainty and resolving government stagnation in certain situation for expediency and public interest. This article reflects the importance of discretion usage because in its application, not all regulation can reach official's duties, authorities and responsibilities comprehensively especially the technical implementation so that it needs the official's subjective action in completing their duties. It is clearly stated in Article 23 the reason why discretion is given, including the legislative requirements which giving decision and/or action choice, not regulated legislation, not complete or not clear legislation, and the emerge of government stagnation for wider interest.

This discretion usage parameter is much more concrete explained as following, first related to choices given by the legislation, in this term, an official is faced with two action choices, from that two alternative choices, the official is given the freedom to choose one of the choices so the chosen choice is called discretion. Second, not regulated legislation, not complete or not clear in terms of there is still no regulation yet related to the technical implementation of the duty, not completed or it has multiple meaning so an official must issue the discretion in order to avoid stagnation in completing the duty. Third, government stagnation emergence, this means as an emergency, urgent, and/or disaster situation. When there is an urgent situation then the officials are given freedom legally to take decisions or actions with the purpose to respond to the situation for the sake of public interest. It explained many times in legislation, moreover, a president can issue a presidential decree to substitute the legislation as the response in facing the urgent situation. The presence of subjective reasons is indeed giving discretion or freedom for investigating officers, public prosecutors, or judges to grant or not the objection plea claims over the arresting towards a suspect/ defendant. Article 31 (1) Penal Code of Indonesia stated that at the request of a suspect or defendant, an investigator or public prosecutor or judge, in accordance with their respective authorities, can hold a suspension of detention with or without money guarantee or personal guarantee based on determined conditions, which means the person sentenced to fine may immediately serve the substitutive light imprisonment without awaiting the term of payment.
Because the use of imprisonment has been regulated in article 20 (1), (2), and (3) Penal Code of Indonesia and with paying attention to article 31 (1) the official involved can conduct light imprisonment with or without bail or person with a certain condition. However, in practice, even though it has fulfilled the conditions legally, the request from the suspect's family or advocate about light imprisonment or suspect/ defendant's detention type alteration along with the bail is not certainly can be grant by law enforcement officer related. The reason is that the law enforcement officer related has discretionary authority to interpret the situation by themselves in order to either reject or grant the request.

Actually, discretion is a policy to break the deadlock, theory about the nation's power consists of positions, those positions must have authority because if not, those positions are meaningless/void. Power is related to position, authority, and responsibility. If there is position and authority but no responsibility, the authority may not materialize. As freedom of thought and action, as stated by Indarti (2010), this matter is fit about the position without discretion is void. This is because an official will lose his creation and willingness to do something for the benefit and welfare of society and seekers of justice. Government officials are 'locked up' because of penal notice existence, finally, society discomfort appeared mostly when the decision taker is not brave enough to do something so stagnation happens in carrying out state administration, especially in financing which causes many budgets and unabsorbed budget (Ispriyarso \& Saadah, 2019; Zulfan et al., 2021). Discretion is still a wishful paradigm and discretion is only existed in legislation as regulated in Government Administration Law. This matter has thought that discretion should not be written, if it were written it will become main duties and function because when the discretion is written, administrative officials' action will be locked up. Discretion controls are tending to be in a grey area; they will be taken in an urgent situation. This discretion is still "rigid" because it has a gradual procedure in conducting. Therefore, the highest holder of discretion is the official who has the highest position. For instance, in Ministry and Institution, in Ministry the highest authority holder is Minister and in the institution is state institution head.

Discretion must meet the requirements, procedures and limitations. Article 30 until Article 32 of Government Administration Law gave option about discretion usage. The first is to exceed the authority, and the second is mixed up with the authority, while the third is that it 
categorized as arbitrary action, so the use of the discretion can be cancelled or not valid. The cancelled or not valid discretions are regulated by articles, including good governance which has concretized so the scope is limited to what is written in the explanation.

\section{CONCLUSION}

The results highlight discretion as one of state administrative officials' right to complete their duties but it has to be the one who has the authority. In Indonesian positive law, the discretionary authority has been regulated in several written legal norms. Like freedom of thought and action, a position without discretion is void. This is because an official will lose his creation and willingness to do something for the benefit and welfare of society and seekers of justice. Government officials are 'locked up' because of penal notice existence, finally, society discomfort appeared mostly when the decision taker is not brave enough to do something so stagnation happens in carrying out state administration, especially in a budget which not optimally managed.

The results would imply that discretion should not be written, if it were written it will become the main duties and function because when the discretion is written, administrative officials' action will be locked up. Discretion controls are tending to be in a grey area; they will be taken in an urgent situation. This discretion is still "rigid" because it has a gradual procedure in conducting. Therefore, the highest holder of discretion is the official who has the highest position. This has led to controversy between scientific discretion and the discretion contained in the Law on Government Administration.

\section{REFERENCES}

Ansori, L. (2017). Diskresi Dan Pertanggungjawaban Pemerintah Dalam Penyelenggaraan Pemerintahan. Jurnal Yuridis, 2(1), 135-150.

Bolifaar, A.H., Jaya, N.S.P., Pujiyono,, \& Arif, F. (2019). Authority of Indonesian attorney in handling the corruption crimes: A perspective of integrated criminal justice system. Journal of Legal, Ethical and Regulatory Issues, 22(5), 1-8.

Darumurti, K. D. (2014). Perspektif Filosofis Konsep Kekuasaan Diskresi Pemerintah. Refleksi Hukum: Jurnal IImu Hukum, 8(1), 41-60.

https://doi.org/10.24246/jrh.2014.v8.i1.p41-60

Elliott, M., Beatson, J., \& Matthews, M. (2011). Beatson, Matthews and Elliott's Administrative Law Text and Materials. Oxford University Press.

Entah, A. R. (2016). Indonesia: Negara Hukum yang Berdasarkan Pancasila. In Seminar Nasional Hukum (Vol. 2, pp. 534-542).
Fathuddin, F. (2015). Tindak Pidana Korupsi (Dugaan Penyalahgunaan Wewenang) Pejabat Publik (Perspektif Undang-Undang Nomor 30 Tahun 2014 Tentang Administrasi Pemerintahan). Jurnal Cita Hukum, 3(1), 95370. https://doi.org/10.15408/jch.v2i1.1844

Gulo, N., Jaya, N.S.P., \& Pujiyono. (2020). Managerial factors of education program performance in correctional institutions. International Journal of Scientific and Technology Research, 9(4), 749-751.

Hadjon, P. M. (2005). Pengantar Hukum Administrasi Indonesia. Yogyakarta: Gadjah Mada University Press

Indarti, E. (2010). Diskresi dan Paradigma: Sebuah telaah filsafat hukum. Semarang: Universitas Diponegoro.

Indarti, E. (2020). Legal philosophy about the performance of the Indonesian national police. Indian Journal of Forensic Medicine and Toxicology, 14(4), 3046-3052

Indarti, E. (2020). Strengthen security and public order: Accountability management in improving the quality of law enforcement. Academic Journal of Interdisciplinary Studies, 9(2), 82-88.

https://doi.org/10.36941/ajis-2020-0025

Ispriyarso, B., \& Saadah, N. (2019). Independence and procedures of tax dispute resolution institutions in Indonesia and East Asian countries. International Journal of Innovation, Creativity and Change, 10(2), 109-117.

Kreveld, J. H. (1983). Beleidsregels in het recht. Kluwer.

Minarno, N. B. (2007). Pembuktian Unsur Penyalahgunaan Wewenang Dalam Tindak Pidana Korupsi. Perspektif, 12(1), 45-56. https://doi.org/10.30742/perspektif.v12i1.363

Mukhlis, R., Indarti, E., Pujiono. (2020). Social and manageria aspects in policy making in criminal prosecution basis. International Journal of Scientific and Technology Research, 9(1), 1637-1639

Muslimin, A. (1985). Beberapa Asas dan Pengertian Pokok Tentang Administrasi dan Hukum Administrasi. Pb. Alumni.

Mustafa, B. (1990). Pokok-Pokok Hukum Administrasi Negara Bandung: Citra Aditya Bakti.

Packer, H. L. (1966). The courts, the police, and the rest of us. The Journal of Criminal Law, Criminology, and Police Science, 57(3), 238-243. https://doi.org/10.2307/1140719

Patiro, Y. M. I. (2012). Diskresi pejabat publik dan tindak pidana korupsi. Keni Media.

Post, R. C. (1984). The Management of Speech: Discretion and Rights. The Supreme Court Review, 1984, 169-236. https://doi.org/10.1086/scr.1984.3536940

Rasyid, A. (2004). Wewenang Mahkamah Konstitusi dan Implikasinya dalam Sistem Ketatanegaraan Republik Indonesia (Doctoral dissertation, Universitas Airlangga).

Ridwan. (2009). Tiga Dimensi Hukum Administrasi dan Peradilan Administrasi. FH UII Press.

Saraswati, R., Ristyawati, A., Basworo, R.S. (2020). Recent developments and changes in the governance of regional legal products in Indonesia: Supervision, evaluation and clarification mechanisms. International Journal of Innovation, Creativity and Change, 12(7), 1-9.

Sihotang, G. A., Pujiyono, P., \& Sa'adah, N. (2017). Diskresi dan tanggung jawab pejabat publik pada pelaksanaan tugas dalam situasi darurat. Law Reform, 13(1), 60-69. https://doi.org/10.14710//r.v13i1.15951

Stroink, F. A. M., \& Steenbeek, J. G. (1989). Inleiding in het staats-en administratief recht. Samsom HD Tjeenk Willink.

Susilo, A. B. (2015). Makna dan kriteria diskresi Keputusan dan/atau tindakan pejabat publik dalam mewujudkan tata pemerintahan yang baik. Jurnal Hukum dan Peradilan, 4(1), 133-152. https://doi.org/10.25216/JHP.4.1.2015.133-152 
Widijowati, D. (2016). Determining Criminal Actions in Corruption: The characteristics of Freies Ermessen Principles. The Southeast Asia Law Journal, 2(1), 56-63. https://doi.org/10.31479/salj.v1i2.7

Yuhdi, M. (2013). Peranan Diskresi dalam Penyelenggaraan Pemerintahan. Likhitaprajna, 15(1), 69-83.
Zulfan,, Saraswati, R., Sukirno,, \& Sa'adah, N. (2021). Redesign of the legislative function of the regional representative council of the republic of indonesia to strengthen regional autonomy. International Journal of Pharmaceutical Research, 13(1), 936-941.

https://doi.org/10.31838/ijpr/2021.13.01.156

https://doi.org/10.6000/1929-4409.2021.10.131

(C) 2021 Gultom et al.; Licensee Lifescience Global.

This is an open access article licensed under the terms of the Creative Commons Attribution Non-Commercial License (http://creativecommons.org/licenses/by-nc/3.0/) which permits unrestricted, non-commercial use, distribution and reproduction in any medium, provided the work is properly cited. 